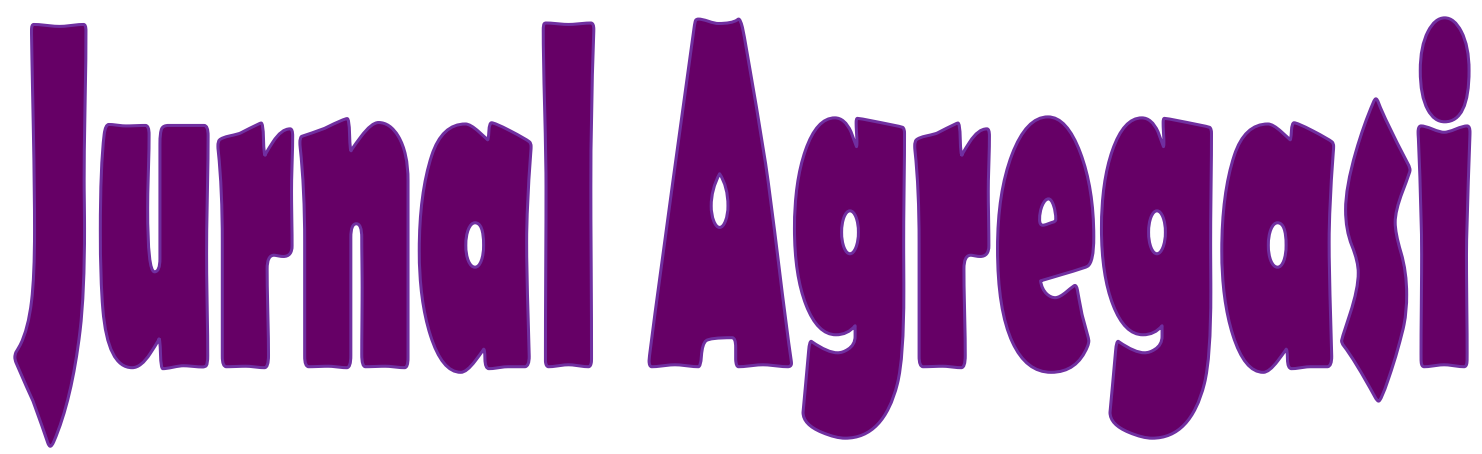

Aksi Reformasi Government dalam Demokrasi

Volume 6 / Nomor 1 / Tahun 2018 / Hal. 1 - 125

Etika Otonomi Daerah Dalam Perspektif Filsafat Pendidikan Fatmawati

Peranan Aparatur Pusat Penelitian dan Pengembangan Daya Air (Puslitbang SDA) dalam Meningkatkan Kualitas Pelayanan Publik Melalui Sistem Informasi Geografis Bidang Sumber Daya Air (SIGSDA) Henri Prianto Sinurat

Revitalisasi Pembangunan Pendidikan Melalui Pendekatan Komunikasi Pendidikan Iwan Koswara

Monitoring dan Evaluasi Pemanfaatan Dana Keistimewaan Daerah Istimewa Yogyakarta Tahun 2013-2017 Laksmi Nurita Tanjung, Dyah Mutiarin dan Eko Priyo Purnomo

Mekanisme Lembaga Adat Melayu Riau dalam Melestarikan Wisata Budaya di Provinsi Riau M.Zainuddin

Implementasi Fungsi Artikulasi dan Agregasi PKS Kota Bandung pada Pemilu 2009 Olih Solihin 


\section{JURNAL AGREGASI}

Merupakan Jurnal Ilmiah berkala yang diterbitkan oleh Program Studi Ilmu Pemerintahan FISIP Unikom. Jurnal ini memuat berbagai hasil penelitian, konsep atau gagasan pemikiran yang terkait dengan reformasi pemerintahan.

\section{DEWAN REDAKSI}

\section{Pembina :}

\section{Dekan FISIP Unikom}

Prof. Dr. Samugyo Ibnu Redjo, Drs., MA.

Penanggung jawab :

Kaprodi Ilmu Pemerintahan Unikom

Dr. Dewi Kurniasih, S.IP., M.Si.

\section{Ketua :}

Nia Karniawati, S.IP.,M.Si.

\section{Mitra Bestari :}

Prof. Dr. Samugyo Ibnu Redjo, Drs.,MA

Prof. Dr. H. Utang Suwaryo, Drs., MA.

Prof. Dr. Cecep Darmawan, S.IP., M.Si.

\section{Tim Editing :}

Dr. Poni Sukaesih K, S.IP.,M.Si.

Tatik Rohmawati, S.IP.,M.Si.

Tatik Fidowaty, S.IP.,M.Si.

Rino Adibowo, S.IP.,M.I.POL

\section{Sekretariat :}

Airinawati, A.Md.

\section{Alamat Redaksi :}

Prodi Ilmu Pemerintahan Unikom

Jl. Dipati Ukur 112-114 Bandung 40132

Telp. 022.2533676 Fax. 022.2506577

OJS : http://ojs.unikom.ac.id/index.php/agregasi

Web : http://jurnalagregasi.ip.unikom.ac.id

Email : jurnalagregasi@email.unikom.ac.id 


\section{KATA PENGANTAR}

Ass. Wr.Wb.

Alhamdulillah, Puji dan Syukur Kita Panjatkan kehadirat Illahi Robbi, atas berkah dan rahmatNya, Jurnal Agregasi Volume 6 Nomor 1 Tahun 2018 dapat kami terbitkan. Jurnal ini merupakan karya ilmiah dari Dosen Ilmu Pemerintahan FISIP Unikom dan Kontributor lain di luar lingkungan Ilmu Pemerintahan FISIP Unikom yang terdiri dari para dosen, pakar maupun praktisi di bidang Pemerintahan.

Dalam Jurnal Agregasi Volume 6 Nomor 1 ini terdapat enam tulisan. Tulisan tersebut merupakan karya ilmiah dari Fatmawati dari STISIP Syamsul Ulum Sukabumi, Henri Prianto Sinurat dari PKP2A IV LAN Banda Aceh, Iwan Koswara dari Unpad Bandung, Laksmi Nurita Tanjung, dkk dari UMY, M.Zainuddin dari Universitas Abdurrab Pekanbaru dan Olih Solihin dari Unikom Bandung. Kepada yang telah berkontibusi memberikan tulisan kami haturkan banyak terima kasih.

Besar harapan kami, karya ilmiah yang terdapat dalam jurnal ini dapat memberikan banyak manfaatnya. Sekian dan terima kasih.

Wss. Wr. Wb.

Bandung, Mei 2018 


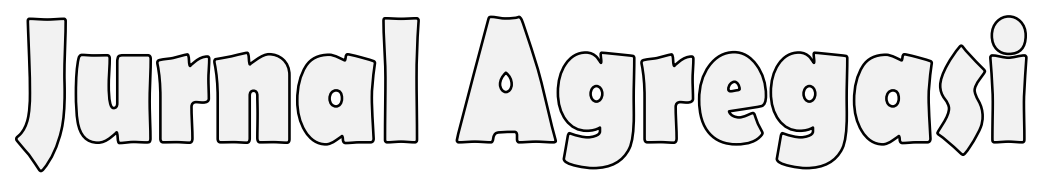

\section{Aksi Reformasi Government dalam Demokrasi \\ e-ISSN: 2579-3047/p-ISSN: 2337-5299/ Vol.6/No.1/Th.2018/Hal.1-125}

\section{DEWAN REDAKSI \\ KATA PENGANTAR \\ DAFTAR ISI}

\section{DAFTAR ISI}

Etika Otonomi Daerah Dalam Perspektif Filsafat Pendidikan

Oleh:

Fatmawati

Peranan Aparatur Pusat Penelitian dan Pengembangan Daya Air

(Puslitbang SDA) dalam Meningkatkan Kualitas Pelayanan Publik Melalui Sistem Informasi Geografis Bidang Sumber Daya Air (SIGSDA)

Oleh:

Henri Prianto Sinurat

Revitalisasi Pembangunan Pendidikan Melalui

Pendekatan Komunikasi Pendidikan

Oleh:

Iwan Koswara

Monitoring dan Evaluasi Pemanfaatan Dana Keistimewaan Daerah

$60-91$

Istimewa Yogyakarta Tahun 2013-2017

Oleh:

Laksmi Nurita Tanjung, Dyah Mutiarin dan Eko Priyo Purnomo

Mekanisme Lembaga Adat Melayu Riau dalam Melestarikan Wisata Budaya di Provinsi Riau.

Oleh:

M.Zainuddin

Implementasi Fungsi Artikulasi dan Agregasi PKS Kota Bandung pada Pemilu 2009.

Oleh:

Olih Solihin 


\title{
MEKANISME LEMBAGA ADAT MELAYU RIAU DALAM MELESTARIKAN WISATA BUDAYA DI PROVINSI RIAU
}

\author{
M.Zainuddin ${ }^{1}$ \\ zainuddin@univrab.ac.id
}

\begin{abstract}
ABSTRAK
Artikel ini mengkaji tentang mekanisme Lembaga Adat Melayu Riau (LAM Riau) dalam melestarikan budaya Melayu yang menjadi salah satu tujuan wisata di Propinsi Riau. LAM Riau harus andil dalam membantu pemerintah daerah untuk melestarikan wisata budaya di Riau, sebab salah satu fungsi LAM Riau tersebut adalah untuk menjaga kelestarian budaya Melayu di Riau. Mekanisme LAM Riau sebagai pressure group dalam hal membantu pemerintah daerah untuk memajukan wisata budaya di Riau. Penyelesaian artikel ini dilakukan dengan penelitian lapangan dan analisa datanya melalui pendekatan kualitatif. Hasil penelitian menunjukan bahwa LAM Riau melakukan mekanisme penanaman nilai-nilai budaya melayu, praktik nilai-nilai budaya melayu dalam masyarakat, dan implementasi arsitektur bangunan melayu. Usaha-usaha yang dilakukan oleh LAM Riau masih belum sampai pada ranah pemangku kebijakan yang bersifat tuntas, melainkan hanya dalam bentuk rekomendasi-rekomendasi yang belum tentu menjadi bahan masukan bagi pemangku kebijakan tersebut.
\end{abstract}

Kata kunci : wisata budaya, pengendalian kapitalisme, kesejahteraan sosial.

\begin{abstract}
This article examines the mechanisms of Riau Malay Customs Organization (LAM Riau) to preserve the malay culture into one tourist destination in the province of Riau. LAM Riau should contribute in helping local governments to preserve the cultural tourism in Riau, because one of the LAM Riau function is to preserve the malay culture in Riau. LAM Riau mechanism as a pressure group in terms of helping local governments to promote cultural tourism in Riau. Completion of this article carried by field research and data analysis through a qualitative approach. The results showed that LAM Riau perform planting mechanism malay cultural values, practices the malay cultural values in society, and implementation of the architecture wither. Attempts were made by LAM Riau still has not reached the realm of policy makers that is completed, but only in the form of recommendations that may not necessarily be input for the policy makers.

Keywords: cultural tourism, control of capitalism, social welfare.
\end{abstract}

\section{PENDAHULUAN}

\section{Latar Belakang Penelitian}

Artikel ini mengkaji tentang mekanisme yang dilakukan oleh Lembaga Adat Melayu (LAM) Riau dalam melestarikan budaya melayu di Riau. Sesuai dengan nama dan tupoksinya, salah satu kegiatan LAM Riau adalah membantu Pemerintah

\footnotetext{
${ }^{1}$ Dosen Prodi Ilmu Pemerintahan Universitas Abdurrab Pekanbaru
} 
Provinsi Riau untuk meningkatkan pariwisata di Riau, terutama wisata budaya. Sebagaimana visi Riau 2020, Riau menjadi pusat kebudayaan melayu se Asia Tenggara pada 2020. Tentu, upaya pencapaian tersebut mengikutsertakan seluruh elemen masyarakat yang ada di Riau, termasuk LAM Riau.

Keterlibatan elemen masyarakat seperti LAM Riau untuk melestarikan budaya melayu didasarkan pada Peraturan Menteri Dalam Negeri Nomor 39 Tahun 2007 tentang Pedoman Fasilitasi Organisasi Kemasyarakatan Bidang Kebudayaan, Keraton, dan Lembaga Adat dalam Pelestarian dan Pengembangan Budaya Daerah serta surat Menteri Dalam Negeri Nomor 188.32/1497.DV pada tanggal 31 Agustus 2007 kepada gubernur dan bupati/walikota se Indonesia sebagai pedoman dalam melakukan pengembangan dikaitkan dengan pelestarian adat dan budaya daerah secara sinergis, terencana dan berkesinambungan.

Berdasarkan ketentuan di atas, maka pekerjaan melestarikan nilai-nilai budaya melayu selain merupakan pekerjaan Pemerintah Provinsi Riau juga menjadi tanggung jawab elemen masyarakat yang bersinggungan dengan pekerjaan tersebut, yakni Lembaga Adat Melayu (LAM) Riau. Tugas berat lembaga ini adalah membantu tugas pemerintah atau menjadi ujung tombak dari pemerintah dalam pelestarian budaya melayu di Riau. Untuk menopang pekerjaan tersebut, maka Pemerintah Provinsi Riau menetapkan Peraturan Daerah Nomor 1 Tahun 2012 tentang Lembaga Adat Melayu Riau. Perda tersebut untuk memberikan landasan hukum kepada LAM Riau untuk melestarikan budaya melayu, sebagai mitra pemerintah daerah dalam upaya memberikan masukan dan bantuan untuk melestarikan budaya melayu di Riau.

Visi Riau 2020 telah ditetapkan sebagai pusat kebudayaan melayu. Landasan hukum untuk melestarikan budaya melayu juga sudah ditetapkan. Terjadi paradoks, sebagai akibat dari perkembangan zaman dan percampuran budaya daerah lain, maka nuansa kemelayuan justru memudar di Riau. Fenomenanya, banyak masyarakat di Riau tidak lagi menggunakan bahasa melayu sebagai bahasa pengantar dalam kehidupan seharian. Selain penggunaan bahasa Indonesia, masyarakat Riau lebih dominan menggunakan bahasa daerah lain (Minang dan Jawa). Arsitektur bangunan kantor pemerintahan di Riau hanya sebagian kecil saja 
menggunakan filosofi arsitektur melayu, terutama kantor-kantor swasta di Riau cenderung bermotif modern (Hidayat, 2011).

Fenomena ini menunjukan bahwa pekerjaan rumah LAM Riau semakin tertantang, sehingga perlu dikaji secara mendalam bagaimana mekanisme LAM Riau untuk melestarikan budaya melayu tersebut. Pengkajian ini untuk memastikan berfungsinya LAM Riau terhadap eksistensi budaya melayu di Riau, sebab budaya melayu di Riau menjadi salah satu tujuan wisatawan untuk datang ke Riau.

Pentingnya kajian ini juga disebabkan LAM Riau merupakan salah satu kelompok penekan (pressure group) yang di Provinsi Riau. Sebagai kelompok penekan, LAM Riau memiliki hak juga untuk menyampaikan aspirasi yang berkembang di tengah masyarakat tentang wisata budaya melayu di Riau yang semakin kurang terpromosikan dengan baik.

\section{Rumusan Masalah Penelitian}

Latar belakang yang telah diuraikan di atas dapat dirumuskan permasalahannya bahwa perlu ada mekanisme LAM Riau untuk ikut serta dalam melestarikan wisata budaya di Provinsi Riau, terutama budaya melayu. Artikel ini akan khusus mengkaji bagaimana mekanisme yang dilakukan oleh LAM Riau tersebut.

\section{Maksud dan Tujuan Penelitian}

Artikel ini bertujuan untuk mengeksplorasi bentuk andilnya LAM Riau terhadap pengembangan pariwisata budaya melayu di Riau, sebab LAM Riau adalah kelompok penekan yang orientasi gerakannya pada budaya melayu. Berfungsinya LAM Riau dipandang akan menambah referensi bagi pemerintah daerah untuk pengembangan wisata melayu di Riau. Perlu juga dianalisa tentang kontribusi LAM Riau yang telah mendapat biaya operasional dari Pemerintah Provinsi Riau terhadap perkembangan pembangunan daerah terutama yang berhubungan dengan budaya melayu di Provinsi Riau. Jadi, artikel ini akan menjadi evaluasi tidak langsung baik bagi pemerintah maupun kelompok penekan seperti LAM Riau yang pendanaan operasionalnya menggunakan anggaran pemerintah. 


\section{Kegunaan Penelitian}

Efek dari penelitian yang dituangkan dalam artikel ini adalah sebagai bentuk evaluasi kinerja LAM Riau yang seharusnya berkontribusi banyak bagi pembangaunan daerah terutama yang terfokus pada pengembangan budaya melayu. Pemerintah juga akan dapat mengetahui celah yang seharusnya diisi untuk perbaikan-perbaikan kinerja dalam upaya pembangunan daerah yang berorientasi wisata budaya.

\section{KAJIAN PUSTAKA}

\section{Kajian Terdahulu}

Lembaga yang berfungsi terhadap eksistensi budaya melayu di Riau sudah dikaji oleh Muhammad Guntur (2014) dengan judul Lembaga Adat Melayu Riau dan Perluasan Kontestasi Politik Identitas Etnis Melayu Riau pada Ranah Politik Lokal. Secara kelembagaan, perluasan kontestasi politik identitas etnis melayu dalam memaknai proses desentralisasi dan demokratisasi, elit etnis yang ada lebih tertarik terlibat pada tatanan pemerintah daerah.

Penelitian Bahri Efendi (2013) dalam jurnal berjudul Negara dan Masyarakat Sipil (Studi Hubungan Pemerintah Daerah Riau dengan Lembaga Adat Melayu Riau). Terjadi simbiosis mutualisme antara keduanya. LAM Riau diutungkan karena pemerintah daerah memberikan bantuan dari APBD sebagai akibat diterbitkannya perda tentang keberadaan LAM Riau. Demikian juga dengan Pemerintah Daerah Riau merasa terbantu tugasnya untuk melesatrikan budaya melayu di Riau. Budaya melayu adalah simbol kenegerian di Riau. Selalu sejalan antara pemerintah daerah Riau dengan Lembaga Adat Melayu Riau terkait dengan agenda atau kebijakan yang dilakukan oleh pemerintah daerah. LAM memberikan kontribusi berupa masukan atau input kepada pemerintah.

Kajian budaya melayu ini bersinggungan dengan banyak hal. Efendy (1998) menyebutkan bahwa manifestasi budaya melayu yang berkaitan dengan sistem sosial, interaksi dan komunikasi antar kelompok adalah nilai-nilai sopan santun, mengutamakan harkat dan martabat, serta memiliki tata pakaian melayu. Lain halnya dengan Suwardi (1987), sebagai budayawan dan sejarawan Riau 
mengemukakan bahwa manifestasi budaya melayu tidak hanya masalah nilai dalam intraksi saja, melainkan juga persoalan nilai dalam arsitektur bangunan melayu. Ciri dari arsitektur bangunan melayu menurut Suwardi dapat dilihat dari bentuk atapnya yaitu lipat pandan, lipat kajang, dan layar. Kemudian ditandai juga dengan ukiranukiran pada dinding, atap, dan selembayung bermotif ulu keris atau merpati dua sejoli. Selain itu, dalam budaya melayu juga terdapat pengaturan seluruh kehidupan, baik yang sifatnya sakral maupun rutinitas biasa.

\section{Kelompok Penekan sebagai Agen Pemerintahan}

Kelompok penekan tidak secara langsung berhubungan dengan tugas negara, itulah yang membedakannya dengan partai politik. Walaupun demikian, terlepas dari perbedaan-perbedaan gradual tersebut, partai politik dan kelompok penekan memainkan peranan yang sangat esensial dalam menjamin kelangsungan suatu sistem politik (Amal dan Panggabean, 2012). Kelompok penekan berjuang untuk kepentingan rakyat, tanpa harus berorientasi kepada kekuasaan. Berbeda dengan partai politik yang berjuang untuk kepentingan rakyat tetapi berorientasi pada kekuasaan. Jalan perjuangan untuk rakyat tersebut yang menjadi poin perbedaan antara keduanya.

Kelompok penekan adalah kelompok yang melakukan tekanan / kritikan atas kekuasaan yang sedang berjalan. Kelompok ini bertindak untuk mempengaruhi kekuasaan, tetapi tidak langsung mengambil bagian dalam kekuasaan tersebut (Duverger, 1984). Jika perbedaan kelompok penekan dengan partai politik terletak pada orientasinya kekuasaan, maka dalam sistem politik ada yang disebut dengan kelompok kepentingan. Perbedaan kelompok penekan dengan kelompok kepentingan terletak pada cara dan sasaran, yakni caranya dengan memberikan tekanan kalau perlu paksaan sedangkan sasarannya ialah tuntutannya harus terpenuhi (Surbakti, 1992).

Menurut Duverger (1984), kelompok penekan dapat digolongkan sebagai berikut: Pertama, kelompok penekan eklusif dan kelompok penekan parsial. Kelompok penekan eklusif hanya mengambil tindakan dalam bidang politik dengan cara memberikan tekanan atas kekuasaan politik, sedangkan kelompok penekan parsial menganggap kegiatan politik merupakan bagian dari kegiatan keseluruhan. 
Kedua, kelompok penekan swasta dan kelompok penekan resmi. Kelompok penekan swasta adalah kelompok penekan yang berada di luar pemerintahan. Sedangkan kelompok penekan resmi berada di lingkungan pemerintahan. Kelompok penekan resmi dibentuk dengan tujuan agar selalu diperhatikan keberadaannya. Ketiga, kelompok penekan asing. Kelompok penekan yang berasal dari luar negeri yang ikut memberikan tekanan tertentu.

Dalam infrastruktur politik sudah lazim terdapat 3 elemen tersebut dalam sebuah negara, yakni partai politik, kelompok penekan dan kelompok kepentingan. Ketiga elemen tersebut adalah alat negara yang berfungsi untuk memperjuangkan kepentingan masyarakat atau sebagai alat penyampai aspirasi dari rakyat kepada pemerintah. Ketiga elemen tersebut berfungsi sesuai dengan domainnya masingmasing.

\section{Strategi Pembangunan Kesejahteraan Sosial}

Disebut sebagai terwujudnya kesejahtaraan apabila terpenuhinya kebutuhan. Ukuran kesejahteraan harus menggunakan parameter yang objektif. Pandangan sosiokultural akan mempengaruh pandangan terhadap kesejahteraan masyarakat. Negara lebih banyak menggunakan parameter yang normatif dan kuantitatif. Sementara masyarakat menggunakan parameter yang subjektif dari apa yang dirasakannya (Soetomo, 2014).

Mewujudkan kesejahteraan sosial harus memaksimalkan seluruh potensi dan sumber daya yang ada. Aktualisasi potensi dan sumber daya untuk mewujudkan kesejahteraan tergantung dari pengelolaannya. Negara dan masyarakat yang kaya sumber daya dan potensi belum tentu menjamin kehidupan masyarakatnya sejahtera apabila tidak tepat dalam pengelolaannya (Soetomo, 2014).

Perubahan orientasi dengan menggunakan pendekatan pemberdayaan masyarakat, semestinya mendorong lembaga-lembaga yang ada di tingkat lokal baik tradisional maupun modern untuk berpartisipasi dalam ruang pengambilan keputusan dan melaksanakan keputusan. Kesejahteraan dapat ditumbuhkan dengan pendekatan yang partisipatif. Partisipasi masyarakat akan dapat dikelola dengan baik apabila diserahkan dengan lembaga resmi yang dibentuk oleh masyarakat lokal 
itu sendiri. Partisipasi masyarakat lokal ini dapat pula disebut sebagai menghargai sumber daya lokal atau keterampilan lokal.

Proses-proses yang digunakan dalam pengembangan masyarakat tidak perlu diimpor dari luar, karena mungkin terdapat dalam masyarakat lokal itu sendiri yang dengan mudah dimengerti dan diterima dengan baik oleh masyarakat lokal (McCowan, 1996). Meskipun demikian, pemerintah sering kali terjebak pada konsep yang besar dari luar, tetapi sulit untuk dilaksanakan di tingkat masyarakat lokal. Pada dasarnya, masyarakat lokal itu sendirilah yang bisa dan sangat mengetahui apa saja yang dibutuhkan olehnya untuk menyelesaikan masalahnya sendiri, pemerintah hanya menyiapkan fasilitasnya.

Dalam konsep pemberdayaan, terdapat tiga hal penting yang perlu dijelaskan. Pertama, pemberdayaan menekankan ekspansi aset dan kemampuan kelompok miskin. Kelompok miskin itu tidak selalu disebut lemah, tetapi mereka sebenarnya memiliki aset dan kemampuan, walaupun tidak sebanyak yang dimiliki oleh kelompok yang kaya. Kegiatan pemberdayaan bertugas untuk berusaha memperluas aset dan kemampuan tersebut. Kedua, perluasan aset dan kemampuan tersebut digerakkan sekaligus difasilitasi dengan cara-cara yang mengedepankan partisipasi, negosiasi, dan akuntabilitas. Bukan menggunakan cara-cara yang kreatif tetapi distruktif. Ketiga, fokus pemberdayaan adalah kelompok miskin. Kelompok ini kehilangan akses pada sumber daya ekonomi dan politik. Mereka hidup dalam kondisi kehilangan akses pada kebutuhan dasar (Ife dan Tesoriero, 2008).

Selama ini, hak-hak masyarakat kelas bawah ditindas. Namun tidak banyak ditemukan organisasi sosial yang mau memperjuangkan hak mereka. Selama ini, institusi sosial yang ada di daerah hampir tidak berdaya menghadapi kekuasaan pemerintah yang tidak berpihak kepada kaum miskin, sehingga tidak pernah mampu menyalurkan aspirasi masyarakat kelas bawah tersebut. Sebagian dari institusi sosial tersebut justeru terkooptasi dan mendukung kepentingan pemerintah atau pengusaha dan kurang memihak kepada kepentingan masyarakat. Para elit lokal juga tidak bisa berbuat banyak, karena mereka sudah menjadi symbolic leader, mempunyai banyak pengikut tetapi tidak diperhitungkan keberadaannya oleh pemerintah (Usman, 2015). 
Dampak dari pelaksanaan strategi pembangunan (pengentasan kemiskinan) yang berorientasi ekonomi menyebabkan bahwa masyarakat sebagai kelompok sasaran hanya sebagai obyek pembangunan, karena kenyataannya warga masyarakat (keluarga peneriman bantuan) merasa kurang diajak berbicara tentang program bantuan di desanya, akibat dari peristiwa ini keterlibatan mereka dalam pemanfaatan bantuan (peningkatan pendapatan), adalah tidak optimal, yang pada gilirannya banyak program bantuan (pengentasan kemiskinan) kurang memberikan hasil seperti yang diharapkan (Zain, 1999).

Zain (1999) menawarkan strategi pengentasan kemiskinan dengan paradigma baru yaitu paradigma kesejahteraan yang memprioritaskan pada aspek menumbuhkan dan mengembangkan wawasan, pengetahuan, ketrampilan, sikap serta perilaku keluarga sasaran agar dapat mengakses sumber daya, modal, pasar, tekonologi serta informasi yang pada gilirannya dapat mewujudkan kesejahteraan secara mandiri. Strategi pengentasan kemiskinan dengan paradigma baru, dengan menggunakan pendekatan kesejahteraan, akan langsung menyentuh basis ekonomi petani (penduduk desa) miskin di samping juga memperhatikan aspek sosial dan budaya masyarakat miskin.

Ada delapan kunci pengentasan kemiskinandalam menerapkan pendekatan kesejahteraan yaitu: Pertama, program penanggulangan kemiskinan haruslah program yang dilandaskan pada kegiatan peningkatan kemampuan untuk menghasilkan income bagi sasaran dan azas income generating capacity berasal dari kegiatan tersebut. Kedua, diterapkannya secara utuh prinsip pembinaan dengan pendekatan kelompok, kemitraan, keluarga, serta berprinsip pada keserasian dan keswadayaan, belajar sambil bekerja serta kepemimpinan dari kelompok sasaran sendiri. Ketiga, dirancangkannya pola pelatihan bagi petugas pembina yang mampu meningkatkan antusiasisme, dedikasi dan kemampuan para petugas pembina dalam menggali dan mengembangkan aspirasi keluarga miskin, terutama dengan pendekatan rural participatory apraisal. Keempat, diterapkannya pola kredit yang mendidik dan disiplin bagi petani kecil sehingga pada akhirnya mempunyai kredibilitas untuk berhubungan dengan bank secara normal. Kelima, diterapkannya cara kerja yang terbuka di antara petugas pembina, sehingga memacu kreativitas dan produktivitas kerja (melaksanakan hubungan yang bersifat dialogis dan 
kolegial), terutama dengan ditanamkannya prinsip melu handarbeni dan melu hangrungkepi pada kelompok sasaran. Keenam, dilaksanakannya latihan kepemimpinan perencanaan partisipatif sehingga tumbuh kesatuan kepemimpinan dan perencanaan dalam penanggulangan kemiskinan. Ketujuh, digunakannya berbagai kredit untuk berbagai macam usaha yang memiliki peluang pasar terbesar. Kedelapan, digunakan prinsip pendekatan kelompok, keluarga, keserasian, kepemimpinan dari kelompok, kemitraan, swadaya, dan belajar sambil bekerja (Zain, 1999).

\section{METODE PENELITIAN}

Penelitian ini menggunakan pendekatan eksploratif dengan metode kualitatif, sebab data yang dikumpulkan melalui metode wawancara dan dokumen-dokumen dari informan akan dapat dikupas dan dianalisa langsung oleh peneliti. Penjelajahan pertayaan dilakukan supaya data yang dibutuhkan dapat tercermin dari wawancara tersebut. Penetapan informasi dilakukan dengan cara purposive sampling, sebab informasi tentang kegiatan LAM Riau tentunya hanya diketahui lebih banyak oleh pengurus LAM Riau dan pemerintah yang bertugas untuk melestarikan wisata di Riau. Penggalian informan dilakukan secara terus menerus sampai datanya jenuh. Setelah data terkumpul, peneliti melakukan uji validitas dan reliabilitas data sebelum dilakukan analisis terhadap data yang ada. Triangulasi data tetap dilakukan supaya data yang telah diperoleh tersebut benar-benar valid. Analisa data dilakukan dengan menggunakan teori yang dipakai pada penelitian ini. Teori difungsikan sebagai alat ukur atau pisau analisa terhadap permasalahan dan data yang diperoleh. Konsep-konsep yang dibahas pada bagian kerangka teori diaplikasikan dalam hal untuk menjawab permasalahan yang ada dalam penelitian, sehingga netralitas peneliti terhadap data dan pengolahan data dapat terjamin.

\section{HASIL PENELITIAN DAN PEMBAHASAN}

Lembaga Adat Melayu (LAM) Riau sebagai salah satu kelompok penekan yang ada di Riau berkontribusi terhadap penyelesaian persoalan yang ada di Riau, termasuk masalah kemiskinan. Sesuai dengan tupoksinya, LAM Riau yang berorientasi kerja pada sektor budaya, maka dalam hal kajian ini tinjauannya adalah 
dalam perspektif peningkatan pariwisata budaya yang terkoneksi dengan kesejahteraan masyarakat Riau.

Kemajemukan identitas masyarakat Riau menyebabkan banyaknya pekerjaan rumah LAM Riau. Diperlukan mekanisme yang tepat untuk menjalankan upaya pelestarian budaya melayu di Riau. Maka dalam artikel ini akan diuraikan tentang mekanisme yang sudah dan akan dijalankan sebagai bentuk eksplorasi upaya-upaya yang dilakukan oleh LAM Riau. Dirgantoro (2004) menyebutkan bahwa keberhasilan dari sebuah strategi terletak pada ketepatan dalam membuat sebuah perencanaan strategi. Perencanaan merupakan hakikat dari menentukan perubahanperubahan yang harus dilakukan dalam usaha mencapai tujuan. Demikian juga halnya dengan LAM Riau dalam mengerjakan pekerjaan rumah untuk melestarikan budaya melayu di Riau. Perlu pengaturan strategi dan mekanisme untuk mendapatkan hasil yang sesuai dengan yang diharapkan.

Melestarikan budaya melayu di Riau akan berdampak pada peningkatan pariwisata budaya di Riau. Peningkatan pariwisata secara langsung akan berimbas ekonomi masyarakat Riau. Selama ini, wisaya budaya melayu di Riau tidak terkelola dengan baik, sehingga tidak ada upaya untuk meningkatkan dan memperbaiki pola wisata budaya tersebut. Efeknya adalah tidak berkontribusinya budaya yang ada di Riau terhadap perkembangan ekonomi masyarakat sekitar. Berbeda halnya dengan yang di Sumatera Barat, Banten, Jawa Barat, Yogyakarta, Bali dan daerah lainya yang memiliki kekhasan budaya. Daerah-daerah tersebut mengelola budaya menjadi tujuan wisata, sehingga memiliki imbas langsung terhadap perekonomian masyarakat.

Pekerjaan LAM Riau bertolak dari visi Riau "Terwujudnya Provinsi Riau sebagai pusat perekonomian dan kebudayaan melayu dalam lingkungan masyarakat yang agamis, sejahtera lahir dan batin di Asia Tenggara tahun 2020”. Pusat budaya melayu bermakna bahwa Riau menjadi indikator utama dalam mengukur dan menilai bagaimana kebudayaan melayu se lingkungan Asia Tenggara. Riau dijadikan referensi mengenai perkembangan kebudayaan melayu.

Indikator tercapainya upaya LAM Riau untuk mewujudkan Riau sebagai pusat kebudayaan melayu adalah: 
1. Terciptanya toleransi, kerja sama yang harmonis dengan pemerintah daerah dan lembaga lainnya,

2. Menguatnya partisipasi masyarakat dalam pelestarian nilai-nilai budaya melayu,

3. Adanya pengembangan dan pembinaan nilai-nilai budaya melayu dalam tunjuk ajar, perilaku dan kearifan serta tata cara berpakaian melayu yang islami di seluruh lapisan masyarakat,

4. Aspek estetika nilai-nilai budaya melayu dalam arsitektur pembangunan di Riau,

5. Terciptanya sarana dan prasarana untuk kegiatan di seluruh kabupaten/kota di Riau.

Berdasarkan indikator tersebut, maka LAM Riau melakukan upaya pelestarian budaya melayu dengan beberapa pendekatan, diantaranya:

\section{Penanaman Nilai-Nilai Budaya Melayu}

Upaya penanaman nilai-nilai budaya melayu dalam kehidupan masyarakat Riau dilakukan oleh LAM Riau dengan mekanisme bekerja sama atau bermitra dengan lembaga lainnya. Syarat dasar kemitraan adalah adanya kesamaan prinsip. Bentuk kerja sama yang dilakukan adalah LAM Riau memberikan kewenangan kepada lembaga lain untuk melestarikan nilai-nilai budaya melayu. LAM Riau telah melakukan kemitraan dengan Dinas Pendidikan Provinsi Riau dan menginstruksikan kepada LAM di seluruh kabupaten/kota di Riau untuk juga bekerja sama dengan Dinas Pendidikan setempat. LAM Riau hanyalah sebuah lembaga non pemerintahan, tidak bisa memberikan instruksi atau perintah kepada orang atau lembaga yang bukan di bawah naungannya. Hanya pemerintah-lah yang boleh menginstruksikan atau yang memiliki hak terhadap warganya. Untuk itu, kerja sama antara pemerintah dalam hal ini dinas pendidikan di tiap kabupaten/kota adalah jalan terbaik untuk menyampaikan keinginan LAM Riau. Selain itu, pendidikan juga menjadi wadah yang tepat untuk sosialisasi.

Elmustian (2003) berpendapat bahwa pendidikan merupakan sarana yang paling tepat untuk memelihara dan mengembangkan nilai-nilai budaya. Karena makna pendidikan adalah mewujudkan tujuan hakiki kebudayaan. Penanaman 
nilai-nilai budaya melayu di sekolah dilakukan dengan memasukan kurikulum muatan budaya melayu sebagai kurikulum muatan lokal.

Kerja sama juga dilakukan oleh LAM Riau dengan sanggar-sanggar kesenian. Sanggar seni yang bernuansa melayu juga sudah barang tentu dimasukan muatan nilai-nilai budaya melayunya. Untuk itu, LAM Riau memberikan materi-materi yang sesuai dengan tujuan muatan budaya melayu terhadap sanggar-sanggar seni yang ada di Riau. Kerja sama juga dilakukan oleh LAM Riau kepada seluruh organisasi kemasyarakatan yang bersinggungan dengan budaya melayu. Penulis tidak menguraikan secara detail ormas yang bersinggungan tersebut, karena relatif banyak yang tersebar di seluruh Riau.

\section{Mempraktikan Nilai-Nilai Budaya Melayu Dalam Masyarakat}

Setelah ada upaya penanaman nilai-nilai budaya dalam masyarakat, maka tentu perlu dipantau juga upaya mempraktikannya. Ada beberapa hal yang perlu dipraktikan oleh masyarakat Riau dalam hal melestarikan budaya melayu di Riau sebagai ikon wisata Riau. Pertama, penggunaan bahasa melayu dalam kehidupan bermasyarakat. Bahasa Indonesia memang berasal dari bahasa melayu, tetapi dengan kondisi sekarang maka bahasa melayu kembali ke akarnya dalam artian yang sempit yakni hanya menjadi milik orang melayu saja. Hasanudin (2003) mengatakan bahasa melayu telah menjadi bahasa daerah dan sangat sempit, bahkan kalah dibandingkan dengan bahasa daerah lainnya.

Kekalahan dominasi bahasa melayu di bumi melayu sendiri dapat dirasakan di Kota Pekanbaru. Bahasa minang menjadi dominan di Pekanbaru. Bahasa pengantar dalam kehidupan sehari-hari, terutama dalam bertransaksi jual beli lebih banyak menggunakan bahasa minang. Orang yang datang ke Pekanbaru justru beranggapan bahasa minang adalah bahasa lokal di Riau. Padahal bahasa minang hanyalah merupakan bahasa yang dianggap pendatang di Riau.

Apabila penggunaan bahasa ini tidak ditekankan penataannya oleh LAM Riau, maka secara perlahan budaya melayu di Riau akan berubah menjadi budaya minang Riau. Kehadiran suku lain di Riau memang tidak bisa dibendung dan dipungkiri lagi, hanya saja bagaimana pemerintah dan LAM Riau membuat ketentuan dan menata kembali supaya penggunaan bahasa melayu sebagai ikon 
budaya melayu juga menjadi keharusan yang tidak bisa dipisahkan dalam sendi kehidupan masyarakat Riau. Inilah yang disebut sebagai penjajahan budaya di Riau oleh budaya lainnya.

Untuk itu, LAM Riau telah mengeluarkan ketentuan tentang keharusan penggunaan bahasa melayu dalam setiap kegiatan di Riau. Berdasarkan kepentingan LAM Riau tersebut, maka Pemerintah Daerah Riau juga mewajibkan kepada seluruh birokrat yang di Riau untuk menggunakan bahasa melayu dan berpantun di setiap awal kegiatan resmi kedinasan. Berdasarkan permasalahan dan usaha LAM Riau di atas, maka sebaiknya LAM Riau belajar dari Pemerintah Malaysia yang mewajibkan penggunaan bahasa melayu sebagai bahasa pengantar dalam setiap kegiatan bermasyarakat. Meskipun penduduk Malaysia berbeda asal negara atau suku bangsanya, tetapi Malaysia tetap bisa menjaga melayu sebagai sebuah bahasa.

Kedua, LAM Riau juga merekomendasikan kepada Pemerintah Daerah setiap kabupaten/kota untuk menerbitkan peraturan daerah tentang penggunaan pakaian melayu, terutama bagi aparatur sipil negara dan sekolah. Penggunaan pakaian melayu juga dilakukan pada kegiatan-kegiatan dalam masyarakat dan kedinasan, termasuk juga pada upacara adat seperti pernikahan dan acara lainnya. Menurut OK.Jamil (2005), pakaian menurut nilai-nilai budaya melayu selain mempunyai nilai keindahan juga untuk menutup aurat agar terhindar dari hal-hal negatif dan merusak moral masyarakat melayu. Makanya, pakaian adat melayu sejalan dengan tuntunan ajaran Islam. Namun, demikian, masih ada pekerjaan rumah lagi bagi LAM Riau, bahwa masih banyak perusahaan yang ada di Riau mempekerjakan kaum perempuan dengan menggunakan pakaian yang tidak sesuai dengan adat istiadat melayu. Pandangan hidup bahwa dimana bumi dipijak disitu langit dijunjung tidak berlaku lagi bagi perusahaan yang ada di Riau.

Ketiga, LAM Riau juga berpartisipasi dan merekomendasikan dalam ragam kegiatan. LAM Riau meminta kepada pemerintah daerah dan LAM se Riau supaya setiap daerah melaksanakan kegiatan resam melayu seperti petang megang menjelang ramadhan, pemasangan lampu colok dalam bulan ramadhan, melestarikan pantun pada kegiatan-kegiatan sakral, mengembangkan pencak silat, 
permainan gasing dan permasinan rakyat melayu lainnya, lagu-lagu melayu, dan ragam kegiatan lainnya.

\section{Mengimplementasikan Arsitektur Bangunan Melayu Di Wilayah Riau}

Budaya melayu juga mengayomi bangunannya. LAM Riau memberikan rekomendasi kepada setiap level pemerintahan supaya membuat bangunan pemerintahan bermotif filosofi melayu. Bentuk bangunan yang bernuansa melayu dengan adanya selembayung dan ukiran ciri khas budaya melayu.

Upaya LAM Riau tersebut tidak terlaksana dengan baik. Hal ini dibuktikan dengan hasil penelitian Wahyu Hidayat (2011) dengan judul Aplikasi Langgam Arsitektur Melayu sebagai Identitas Kawasan Menuju Kota Berkelanjutan. Penelitian ini dilakukan di sepanjang Jalan Sudirman Kota Pekanbaru, hasilnya menunjukan bahwa hanya $31 \%$ bangunannya berarsitektur langgam melayu.

Secara umum, di Provinsi Riau telah membuat bangunan atau gedung pemerintahan dengan nuansa langgam melayu. Namun, untuk bangunan atau gedung swasta masih belum dimaksimalkan. Termasuk juga gedung-gedung milik BUMN dan BUMD yang ada di Riau, masih belum terlihat bernuansa melayunya. Sebagai sebuah kelompok penekan, LAM Riau harusnya berkontribusi banyak dan perihatin melihat kondisi bangunan yang ada di Riau. Keprihatinan tersebut sebaiknya dtunjukkan dalam bentuk tuntutan kepada pemangku kebijakan untuk membuat aturan khusus tentang nuansa atau bentuk bangunan yang ada di Riau. Jika usaha tersebut terealisasi, maka keindahan Riau sebagai daerah yang memproduksi budaya melayu akan terlihat dengan bentuk fisiknya. Hal ini tentu akan menarik pemandangan dan mendorong wisatawan untuk hadir di Riau.

Mekanisme melestarikan budaya melayu di Riau sebagai ikon wisata di Riau yang dilakukan olh LAM Riau memiliki banyak kendala, diantaranya: Pertama, faktor pergantian kepemimpinan di kabupaten/kota. Tidak semua pemimpin di daerah peduli dengan keberadaan dan kelestarian budaya melayu, sehingga menjadi terhambat program LAM Riau dan LAM di daerah untuk merealisasikan kegiatannya. Kendala tersebut terdapat pada penganggaran pemerintah daerah untuk kegiatan LAM. Kepedulian pemimpin di daerah dapat dilihat dan dianalisa dari visi kepemimpinannya setelah mereka terpilih menjadi pimpinan. 
Kedua, pengurus LAM Riau banyak yang rangkap jabatan dengan organisasi kemasyarakatan lainnya. Akibatnya, fokus perhatian untuk mengurus LAM Riau menjadi terbagi. Hal ini terjadi karena memang pengurus LAM Riau merupakan tokoh-tokoh masyarakat melayu yang ada di Riau. Secara otomatis mereka akan menjadi perhatian dan akan diminta juga untuk mengelola organisasi lainnya yang sejalan dengan kemampuan mereka masing-masing. Sebaiknya ada aturan yang menyebutkan batas kewajaran untuk aktif diorganisasi lain selain LAM Riau jika pengurus yang ada itu mau atau benar-benar mau mengurus LAM Riau.

\section{KESIMPULAN DAN REKOMENDASI}

Keberadaan LAM Riau merupakan 'angin segar' bagi masyarakat Riau. Sebab, Riau yang memiliki visi sebagai pusat kebudayaan tidak bisa hanya diusahakan oleh pemerintah daerah saja, tetapi juga harus andil seluruh elemen masyarakat. Elemen masyarakat tersebut terhimpun atau diwakili oleh LAM Riau. Mekanisme upaya melestarikan budaya melayu di Bumi Lancang Kuning sehingga menjadi ikon wisata budaya di Riau sudah dilakukan secara maksimal oleh LAM Riau dan unsur-unsur yang bekerja sama dengannya, namun tetap saja usaha tersebut mendapat kendala. Penulis merekomendasikan supaya LAM Riau mau belajar ke negara lain yang fokus mempertahankan budaya melayu di negerinya, atau belajar dengan daerah lain yang tetap kental mempertahankan budayanya dimanapun dan kapanpun tentang keberadaan masyarakatnya.

\section{PENGHARGAAN}

Ucapan terima kasih yang terhingga kepada seluruh komponen yang berkontribusi terhadap penyelesaian penelitian ini, terutama kepada Pengurus Lembaga Adat Melayu (LAM) Riau. Terima kasih juga kepada pengelola Jurnal Agregasi Unikom Bandung yang telah memberikan fasilitas untuk menerbitkan hasil penelitian ini, sehingga dapat berkontribusi untuk banyak pihak. Tidak terlupakan juga bagi pihak Universitas Abdurrab yang memberikan kesempatan atau waktu bagi peneliti untuk menyelesaikan penelitian ini di antara kesibukan lainnya di Universitas Abdurrab. 


\section{DAFTAR PUSTAKA}

Adisasmita, R. (2011). Manajemen Pemerintah Daerah. Graha Ilmu, Yogyakarta. Amal, TA \& Panggabean, SR. (2012). Politik Syariat Islam. Jakarta: Pustaka Alvabet.

Bahri, E. (2013). Negara dan Masyarakat Sipil (Studi Hubungan Pemerintah Daerah Riau dengan Lembaga Adat Melayu (LAM) Riau. Jurnal Nahkoda, $13,118-129$.

Dirgantoro. (2004). Manajemen Stratejik: Konsep, Kasus, dan Implementasi. Grasindo. Jakarta.

Duverger, Maurice. Partai Politik dan Kelompok-kelompok Penekan, Jakarta , 1984, Bina Aksara.

Elustin, R. (2003). Alam Melayu. Unri Press. Pekanbaru.

Guntur, M. (2004). "Lembaga Adat Melayu Riau dan Perluasan Kontestasi Politik Identitas Etnis Melayu Riau pada Ranah Politik Lokal (Studi Komparasi Kasus Lembaga Adat Melayu Bengkalis dengan Lembaga Adat Melayu Pekanbaru)". Universitas Gadjah Mada.

Hasanudin. (2003). Pemeliharaan dan Pengembangan Budaya Melayu. Unri Press. Pekanbaru.

Hidayat, W. (2011). "Aplikasi Langgam Arsitektur Melayu sebagai Identitas Kawasan Menuju Kota Berkelanjutan”. Universitas Riau.

Ife, J \& Tesoriero, F. (2008). Community Development: Alternatif Pengembangan Masyarakat Di Era Globalisasi. Terj. Pustaka Pelajar. Yogyakarta.

Jamil, OKN. (2005). Pakaian Tradisional Melayu Riau. LPUN Press. Pekanbaru.

McCowen, L. (1996). A Social Work Approach to Post Genocide Trauma Recoverry for the Rwandese Community. Master of Social Work Thesis. University of New Castle. Australia.

Soetomo. (2014). Kesejahteraan dan Upaya Mewujudkannya dalam Perpsektif Masyarakat Lokal. Pustaka Pelajar. Yogyakarta.

Surbakti, R. (1992). Memahami Ilmu Politik. PT Gramedia Widiasarana. Jakarta.

Suwardi. (1987). Arsitektur Tradisional Daerah Riau. IDKD. Pekanbaru. . (2008). Dari Melayu ke Indonesia. Pustaka pelajar.Yogyakarta.

Usman, S. (2015). Esai-Esai Sosiologi Perubahan Sosial. Pustaka Pelajar. Yogyakarta.

Wibowo, F. (2007). Kebudayaan Menggugat. Pinus Book Publisher. Yogkayarta.

Zain, M. (1999). "Reformasi Pengentasan Kemiskinan: Dari Pendekatan Ekonomi ke Pendekatan Kesejahteraan”. Masyarakat, Kebudaya-an dan Politik. Th XII, No 4, 79-96. 